\title{
Pengaruh Kepemilikan Manajerial, Manajemen Laba Dan Ukuran Perusahaan Terhadap Kinerja Perusahaan
}

\author{
Yoli Hermeizi, Zefriyenni, Hilda Mary, Lusiana, Nila Pratiwi \\ Universitas Putra Indonesia YPTK Padang, Indonesia \\ hildamary@upiyptk.ac.id
}

\begin{abstract}
Abstrak
This study aims to examine how much influence managerial ownership, earnings management and company size have on company performance. The population in this study was property and real estate companies listed on the Indonesian Stock Exchange (IDX) for the 2014-2018 period. Sampling in this study using purposive sampling method obtained 30 companies with a research period of 5 years from 2014-2018. The analysis method used in this research is panel data analysis using eviews 9 .

The results obtained partially (t-test) show that managerial ownership and earnings management have no significant effect on firm performance, while firm size has a significant effect on firm performance. The simultaneous results (f-test) of managerial ownership, earnings management and firm size are significant on firm performance. The contribution of managerial ownership, earnings management and company size to company performance is $84 \%$, while the remaining $16 \%$ is influenced by other variables that are not included in the model in this study.
\end{abstract}

Kata kunci: Kepemilikan Manajerial, Manajemen Laba, Ukuran Perusahaan, dan Kinerja Perusahaan

\section{Pendahuluan}

Dinamika perekonomian global dari tahun ketahun memberikan tekanan terhadap pertumbuhan ekonomi domestik. Perlambatan pertumbuhan ekonomi tersebut telah memberikan dampak yang kurang menguntungkan. Menanggapi kondisi yang demikian, pemerintah mengeluarkan berbagai kebijaksanaan dalam rangka menjaga stabilitas makro dan mendorong pemulihan perekonomian. Kebijakan pertama mengatasi persoalan ekonomi dengan mendorong daya saing industri nasional melalui deregulasi, debirokratisasi, serta penegakan hukum dan kepastian usaha. Kedua, pemerintah akan mempercepat proyek strategis nasional dengan menghilangkan berbagai hambatan dalam pelaksanaan dan penyelesaian proyek strategis nasional. Pemerintah juga akan memperkuat peran kepala daerah untuk melakukan dan memberikan dukungan percepatan pelaksanaan proyek tersebut. Ketiga, meningkatkan investasi di sektor property. Dalam hal ini pemerintah mengeluarkan kebijakan untuk mendorong pembangunan perumahan, khususnya untuk masyarakat berpenghasilan rendah, serta membuka peluang investasi yang lebih besar disektor property.

Kebijakan ekonomi tahap pertama akan memperkuat industri nasional, mengembangkan usaha mikro menengah, koperasi, dan memperlancar perdagangan antar daerah. Pemerintah menegaskan kebijakan ini sukses memajukan ekonomi dalam negeri, maka pemerintah butuh kerjasama dan dukungan dari semua pihak. Kondisi perekonomian suatu negara akan membawa dampak pada perusahaan yang bergerak disektor property dan real estate. Sehingga dengan adanya kebijkan pemerintah Indonesia akan membawa peluang besar bagi perusahaan property dan realestate, yang akan berdampak pada peningkatan kinerja perusahaan.

Perusahaan dengan kinerja keuangan yang baik akan menghasilkan laba yang maksimal sehingga memiliki tingkat pengembalian investasi yang tinggi. Dalam penelitian ini, rasio profitabilitas yang digunakan adalah Return on Asset (ROA). Return on Asset (ROA) digunakan sebagai indikator kinerja keuangan perusahaan karena ROA dan lebih merepresentasikan kepentingan pemegang 
saham menurut (Kasmir, 2014). Nilai ROA yang semakin besar menunjukkan kinerja perusahaan yang semakin baik. Para investor menyukai perusahaan yang profitable dikarenakan tingkat pengembalian yang tinggi.

Naik turunnya kinerja keuangan perusahaan salah satunya dipengaruhi oleh ukuran perusahaan. Ukuran perusahaan dilihat dari total aset yang dimiliki oleh perusahaan yang dapat dipergunakan untuk kegiatan operasi perusahaan. Semakin besar total aset yang dimiliki suatu perusahaan, semakin besar pula ukuran perusahaan. Semakin besar aset maka semakin besar modal yang ditanam, sementara semakin banyak penjualan, maka semakin banyak juga perputaran hutang dalam perusahaan (Sujarweni, 2015). (Sujianto, 2001) ukuran perusahaan menggambarkan besar kecilnya suatu perusahaan yang ditunjukkan oleh total aktiva, jumlah penjualan, rata-rata total penjualan dan rata-rata total aktiva. Beberapa penelitian telah menemukan bahwa ada hubungan positif antara ukuran perusahaan dan kinerja perusahaan.

Faktor lain yang menyebabkan naik turunnya kinerja keuangan perusahaan adalah dipengaruhi oleh struktur kepemilikan. Faktor selanjutnya adalah manajemen laba yaitu campur tangan manajemen dalam proses pelaporan keuangan dengan tujuan untuk menguntungkan perusahaan (manager). Salah satucara untuk mengukur manajemen laba adalah dengan menggunakan proksi Discretionary Accrual (DA). Discretionary Accrual adalah komponen akrual yang berada dalam kebijakan manajer, artinya manajer memberi intervensinya dalam proses pelaporan akuntansi. Keleluasaan dalam pengelolaan perusahaan dapat menimbulkan penyalahgunaan wewenang.

ROA (Return On Assets) menurut (Kasmir 2014) yaitu "return ontotal assets merupakan rasio yang menunjukkan hasil (return) atas jumlah aktiva yang digunakan dalam perusahaan". ROA yang baik adalah ROA yang meningkat setiap tahunnya. Semakin besar ROA menunjukkan kinerja yang semakin baik. Nilai Kepemilikan Manajerial yaitu jumlah saham manajer dan jumlah saham komisaris dibagi jumlah saham yang beredar dan cenderung naik. Kondisi ini berbanding terbalik dengan nilai ROA sehingga hal ini tidak sesuai dengan pendapat (NiWayan, 2010) Semakin besarnya kepemilikan manajerial dalam perusahanan maka semakin produktif tindakan manajer dalam memaksimalkan nilai perusahaan. Jika dilihat variabel ukuran perusahaan yang diukur dengan melognaturalkan jumlah total aktiva maka diketahui nilai ln aktiva perusahaan property dan real estate adalah senantiasa mengalami kenaikan. Menurut pendapat (Ali, 2008) ukuran perusahaan dapat dinilai dari beberapa segi. Besar kecilnya suatu perusahaan dapat didasarkan pada total nilai aktiva, total penjualan, kapitalisasi pasar, jumlah tenaga kerja dan sebagainya. Semakin besar aktiva suatu perusahaan maka akan semakin besar pula modal yang ditanam, semakin besar total penjualan suatu perusahaan maka akan semakin banyak juga perputaran uang dan semakin besar kapitalisasi pasar maka semakin besar pula perusahaan dikenal masyarakat.

\section{Metodologi Penelitian}

\subsection{Jenis Data Dan Sumber Data}

Jenis data yang digunakan dalam penelitian ini adalah data kuantitatif dan jenis sumber data dalam penelitian ini adalah data sekunder yang diperoleh dari laporan keuangan perusahaan property dan real estate yang terdaftar di Bursa Efek Indonesia (BEI) pada periode 2014-2018. Data diperoleh dari Bursa Efek Indonesia atau dari website milik Bursa Efek Indonesia yaitu www.idx.co.id, serta sumber lain yang relevan seperti dari website perusahaan dan Indonesia Capital Market Directory (ICMD).

\subsection{Populasi dan Sampel}

Populasi yang digunakan dalam penelitian ini adalah semua perusahaan property dan real estate yang terdaftar di Bursa Efek Indonesia yang mempublikasikan laporan keuangannya. Dalam hal ini, kita mengenal istilah populasi yang terbatas dan populasi yang tidak terbatas. Dalam penelitian 
ini yang menjadi populasi nya adalah sebanyak 61 perusahaan property dan real estate yang ada di Indonesia periode 2014-2018.

Pemilihan sampel dilakukan dengan teknik porposive sampling dimana sampel yang diambil dalam penelitian ini adalah sebanyak 30 perusahaan property dan real estate yang terdaftar di BEI periode $2014-2018$ yang memenuhi kriteria.

\subsection{Pengukuran Variabel}

Indikator yang digunakan dalam kinerja perusahaan adalah Returm On Asset (ROA). Menurut (Hery, 2015), ROA merupakan rasio yang menunjukkan seberapa besar kontribusi asset dalam menciptakan laba bersih. Dengan kata lain, rasio ini digunakan untuk mengukur seberapa besar jumlah laba bersih yang akan dihasilkan dari setiap rupiah dana yang tertanam dalam total asset. Rasio ini dihitung dengan membagi laba bersih terhadap total asset.

Adapun rumus untuk menghitung return on assets (ROA) :

$$
\text { Return On Asset }=\frac{\text { Laba bersih }}{\text { Total aset }} \times 100
$$

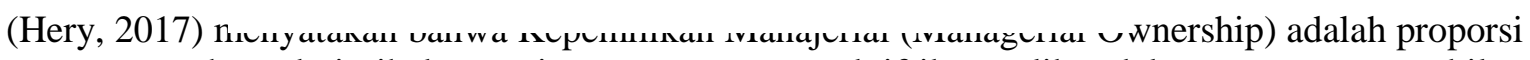
pemegang saham dari pihak manajemen yang secara aktif ikut terlibat dalam proses pengambilan keputusan perusahaan. Kepemilikan manajerial diukur sesuai dengan persentase jumlah saham yang proporsi pemegang saham dari pihak manajerial yang secara aktif ikut dalam pengambilan keputusan perusahaan (direktur dan komisaris).

Perhitungan Kepemilikan Manajerial dapat dirumuskan sebagai berikut:

$$
\text { K. Manajerial }=\frac{\text { Jumlah Saham Manajerial }}{\text { Total Saham Beredar }} \times 100
$$

(Alzoubi, 2012) mendefinisikan manajemen laba sebagai intervensi (manajemen) dalam proses pelaporan keuangan (yang ditujukan) untuk kepentingan eksternal dengan tujuan untuk mendapatkan keuntungan pribadi. Menurut (Hendri, 2019).

Berikut rumus untuk mencari Manajemen Laba adalah sebagi berikut:

$$
\begin{gathered}
\text { Manajemen Laba }=\frac{\text { Akrual Modal Kerja }}{\text { Penjualan }} \\
\text { Akruaı ıvıodaı kerja }=\Delta \mathrm{AL}-\Delta \mathrm{HL}-\Delta \mathrm{NaS}
\end{gathered}
$$

Keterangan :

$\Delta \mathrm{AL}=$ Perubahan aktiva lancar pada periode akhir $\mathrm{t}$

$\Delta \mathrm{HL}=$ Perubahan hutang lancar pada akhir periode $\mathrm{t}$

$\Delta$ Kas $=$ Perubahan kas dan ekuivalen kas pada akhir periode $\mathrm{t}$

Menurut (Sholichah, 2015) ukuran perusahaan dapat diartikan sebagai suatu perbandingan besar atau kecilnya usaha dari suatu perusahaan atau organisasi.

Perhitungan Ukuran Perusahaan dapat dirumuskan sebagai berikut: 
Model statistik untuk regresi linier berganda dapat dinyatakan sebagai berikut :

$$
\text { ROAit }=\alpha+\beta 1 \text { KMit }+\beta 2 \text { MLit }+\beta 3 \text { SIZEit }+\mathrm{e}
$$

Keterangan:

\begin{tabular}{|c|c|}
\hline ROA & $=$ Kinerja Perusahaan \\
\hline$\alpha$ & $=$ Konstanta \\
\hline$\beta 1 \beta 2 \beta 3$ & $=$ Koefisien Regresi \\
\hline KM & $=$ Kepemilikan Manajerial \\
\hline ML & = Manajemen Laba \\
\hline Size & $=$ Ukuran Perusahaan \\
\hline 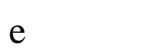 & $=$ Standar Error \\
\hline
\end{tabular}

\section{Hasil dan Pembahasan}

\section{Uji Normalitas}

Uji normalitas bertujuan untuk mengetahui apakah dalam model residual berdistribusi normal atau tidaknya. Dalam penelitian ini uji normalitas dilakukan dengan ujijarque-bera. Residual dikatakan berdistribusi normal apabila memiliki nilai nilai diatas atau sama dengan 0,05. Hasil dari uji normalitas dapat dilihat dari gambar 1 dibawah ini:

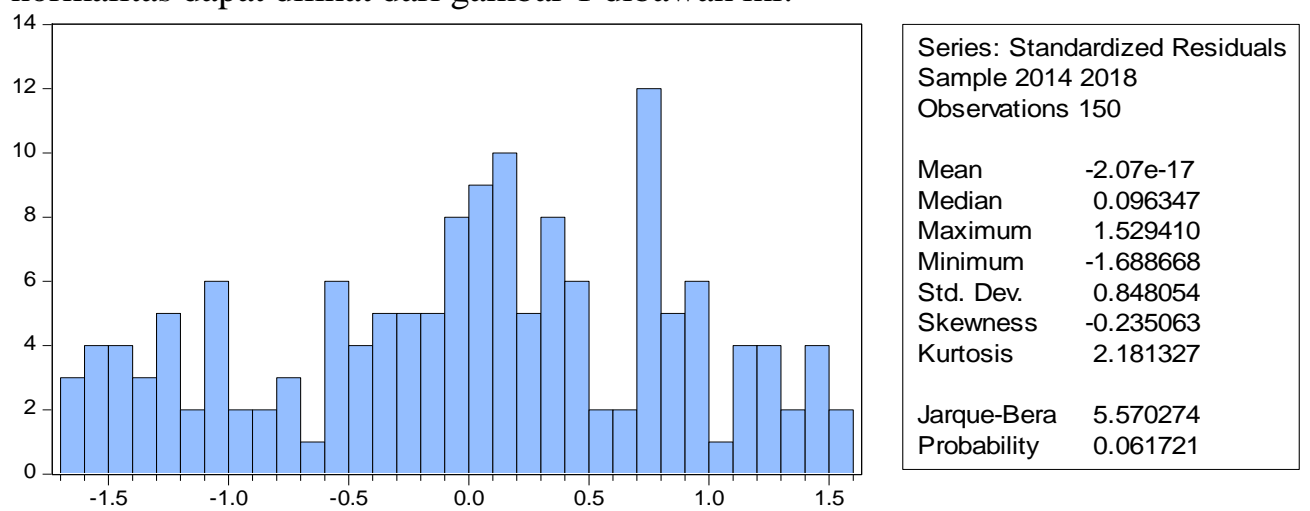

Gambar 1: Hasil Uji Normalitas

Berdasarkan histogram pada uji normalitas menunjukkan residual penelitian memiliki ketinggian antara stem yang tidak terlalu jauh antara satu dengan yang lainnya, dan pola sebaran residual dikatakan juga tidak terlalu rapat dan ada gap. Distribusi residual penelitian dapat dilihat pada hasil uji Jarque- Bera pada gambar diatas diketahui bahwa nilai Jarque-Bera sebesar 5,57 dengan probability 0,06 karena nilai profitabilitas $0,06>$ dari 0,05 maka dapat dikatakan bahwa residual dalam model penelitian ini telah normal.

\section{Uji Multikolonieritas}

Pengujian multikolinearitas dilakukan untuk mengetahui hubungan yang terjadi antar variabel indenpen. Pengujian multikolinearitas dilakukan dengan menggunakan corelation matrix. gejala multikolinieritas terjadi apabila masing-masing variabel independen yang digunakan memiliki koefisien korelasi > 0.80. Jika masing-masing variabel independen memiliki koefisien korelasi < 0.80 maka variabel independen terbebas dari masalah multikolinieritas. Berdasarkan hasil 
pengujian multikolinearitas yang telah dilakukan diperoleh ringkasan hasil terlihat pada tabel 1 dibawah ini :

Table 1: Hasil Uji Multikolinearitas (Corelation Matrix)

\begin{tabular}{lccc} 
& X1_KM & X2_MI & X3_SIZE \\
\hline X1_KM & 1,00 & 0,04 & 0,00 \\
\hline X2_MI & 0,04 & 1,00 & $-0,07$ \\
\hline X3_SIZE & 0,00 & $-0,07$ & 1,00
\end{tabular}

Pada tabel 1 diatas hasil uji multikolinearitas (corelation matrix) terlihat bahwa masing-masing independent variable yang digunakan dalam penelitian telah memiliki koefisien korelasi dibawah < 0,80 sehingga dapat disimpulkan bahwa masing-masing independent variable yang digunakan dalam penelitian ini telah terbebas dari gejala multikolinearitas.

\section{Uji Heteroskedastisitas}

Pengujian heteroskedastisitas dilakukan untuk mengetahui pola sebaran data yang mendukung masing-masing variabel penelitian. Pengujian heteroskedastisitas dilakukan dengan menggunakan model Glejser. Di dalam model tersebut gejala heteroskedastisitas tidak akan terjadi bila nilai probability chi-square yang dihasilkan dalam pengujian berada diatas 0.05 . Berdasarkan hasil pengujian heteroskedastisitas diperoleh ringkasan hasil terlihat pada tabel 2 dibawah ini:

Table 2: Hasil Uji Heteroskedastisitas (Glejser)

Heteroskedasticity Test: Glejser

\begin{tabular}{llll}
\hline F-statistic & 0,62 & Prob. F(3,146) & 0,60 \\
\hline Obs*R-squared & 1,89 & Prob. Chi-Square(3) & 0,59 \\
\hline Scaled explained SS & 2,12 & Prob. Chi-Square(3) & 0,55
\end{tabular}

Berdasarkan tabel 2 terlihat bahwa nilai probability observasi R-squared yang dihasilkan adalah sebesar 0,59. Hasil yang diperoleh tersebut menunjukkan bahwa nilai probability yang dihasilkan menunjukkan 0,59>0,05 sehingga dapat disimpulkan bahwa seluruh variabel penelitian baik variabel independen maupun variabel dependen yang akan dibentuk kedalam model regresi data panel telah terbebas dari gejala heteroskedastisitas.

\section{Uji Autokorelasi}

Pengujian ini bertujuan untuk mengetahui ada atau tidaknya korelasi antara kesalahan-kesalahan yang muncul pada data yang diurutkan berdasarkan waktu (time series). Uji untuk mendeteksi adanya gejala autokorelasi adalah uji yang dikembangkan oleh Durbin dan Watson, yang dikenal dengan statistik Durbin-Watson (DW). Salah satu ukuran dalam menetukan ada tidaknya masalah autokorelasi dengan uji Durbin-Watson (DW) dengan ketentuan sebagai berikut : Terjadi autokorelasi positif, jika nilai DW dibawah -2 (DW < -2), Tidak terjadi autokorelasi, jika nilai DW berada di antara -2 dan +2 atau $-2<$ DW $<+2$, Terjadi autokorelasi negatif jika DW di atas +2 atau DW $>+2$.

Table 3: Uji Autokorelasi dengan Uji Durbin-Watson

\begin{tabular}{ll} 
Mean dependent var & 3,52 \\
\hline S.D. dependent var & 4,80 \\
\hline Sum squared resid & 107,16 \\
\hline Durbin-Watson stat & 1,89
\end{tabular}


Berdasarkan Tabel 3 diatas, dapat dilihat nilai statistik Durbin-Watson adalahsebesar 1,89.Perhatikan bahwa karena nilai statistik Durbin-Watson terletak di antara 1 dan 3, yakni $-2<1$, $89<2$ maka asumsi non-autokorelasi terpenuhi. Dengan kata lain, tidak terjadi gejala autokorelasi pada residual, atau dapt dikatakan data terbebas dari gejala autokorelasi.

\section{Hasil Uji Chow}

Table 4: Hasil Uji Chow

\begin{tabular}{llll} 
Effects Test & Statistic & d.f. & Prob. \\
\hline Cross-section F & 5,99 & $(29,117)$ & 0,00 \\
\hline Cross-section Chi-square & 136,64 & 29 & 0,00
\end{tabular}

Berdasarkan tabel 4 diatas dapat diketahui bahwa nilai probabilitas cross-section Chi-Square adalah sebesar 0,00<0,05 maka dapat disimpulkan H_aditerima dan $\mathrm{H} 0$ ditolak, sehingga model fixed effect lebih baik digunakan dibandingkan dengan model common effect.

\section{Hasil Uji Hausman}

Table 5: Hasil Uji Hausman

Correlated Random Effects - Hausman Test

\begin{tabular}{llll}
\hline Test Summary & Chi-Sq. Statistic & Chi-Sq. d.f. & Prob. \\
\hline Cross-section random & 7,81 & 3 & 0,04
\end{tabular}

Berdasarkan hasil uji uji hausman pada tabel 5 dapat diketahui bahwa nilai probability Chi-square adalah 0,04 $<0,05$ maka dapat disimpulkan bahwa H0 ditolakdan dan Ha diterima, sehingga model yang digunakan sebaiknya adalah model fixed effect dibandingkan dengan model random effect.

\section{Hasil Uji Lagrange Multiplier}

Table 6: Lagrange Multiplier Tests for Random Effects

\begin{tabular}{cc} 
& Cross-section \\
\hline Breusch-Pagan & 63,31 \\
\hline$(0,00)$
\end{tabular}

Berdasarkan hasil uji ML pada tabel 6 dapat diketahui bahwa nilai probability Chi-square adalah $0,00<0,05$ maka dapat disimpulkan bahwa $\mathrm{H} 0$ ditolak dan dan Ha diterima, sehingga model yang digunakan sebaiknya adalah model random effect dibandingkan dengan model effect.

Table 7: Hasil Pemilihan Model Penelitian

\begin{tabular}{llccc}
\multicolumn{1}{c}{ Uji } & \multicolumn{1}{c}{ Model } & Sign. & Pembanding & Hasil \\
\hline Uji Chow & $\mathrm{H}_{0}=$ Common Effect & 0,00 & 0,05 & Fixed Effect \\
& $\mathrm{H}_{\mathrm{a}}=$ Fixed Effect & & & \\
\hline Uji Hausman & $\mathrm{H}_{0}=$ Random Effect & 0,04 & 0,05 & Fixed Effect \\
& $\mathrm{H}_{\mathrm{a}}=$ Fixed Effect & & & \\
\hline Uji Lagrange & $\mathrm{H}_{0}=$ Command Effect & 0,00 & 0,05 & Random Effect \\
Multiplier & $\mathrm{H}_{\mathrm{a}}=$ Random Effect & & & \\
\hline \multicolumn{2}{c}{ Hasil Pemilihan Model Penelitian } & & Model Fixed Effect
\end{tabular}

Berdasarkan pengujian yang telah dilakukan dengan menggunakan uji chow dengan pendekatan model Fixed Effect dan uji hausman pemilihan model yang telah dilakukan dengan pendekatan 
Jurnal EKOBISTEK, Vol.10, No. 2. April 2021, Hal 16-27, ISSN : 2301-5268 | E-ISSN: 2527-9483 Copyright@2021 by LPPM UPI YPTK Padang

model Random Effect serta uji lagrange multiplier dengan pendektan Cammon Effect. Maka dari ketiga model tersebut dipilih salah satu yang terbaik yaitu Fixed effect. 


\section{Hasil Analisis Regresi Data Panel}

Analisis regresi data panel dalam penelitian ini bertujuan untuk mengetahui pengaruh kepemilikan manajerial, manajemen laba dan ukuran perusahaan terhadap kinerja perusahaaanpada perusahaan property dan real estate yang terdaftar di Bursa Efek Indonesia periode 2014-2018.

Berdasarkan pengujian yang telah dilakukan dengan menggunakan uji chow dengan pendekatan model Fixed Effect dan uji hausman pemilihan model yang telah dilakukan dengan pendekatan model Fixed Effect serta uji lagrange multiplier dengan pendektan Random effect. Maka dari ketiga model tersebut dipilih salah satu yang terbaik yaitu Fixed effect. Kemudian sebelum pemilihan model, data dinyatakan telah lolos dari asumsi klasik, sehingga estimasi konsisten dan tidak bias. Hasil estimasi model regresi data panel sebagai berikut :

Table 8: Hasil Estimasi Fixed Effect Model

\begin{tabular}{|c|c|c|c|c|}
\hline Variable & Coefficient & Std. Error & t-Statistic & Prob. \\
\hline X1_KM & $-0,01$ & 0,01 & $-0,42$ & 0,67 \\
\hline$\overline{\mathrm{X} 2 \_\mathrm{MI}}$ & 0,02 & 0,03 & 0,56 & 0,58 \\
\hline X3_SIZE & $-1,67$ & 0,37 & $-4,48$ & 0,00 \\
\hline $\mathrm{C}$ & 12,57 & 2,54 & 4,95 & 0,00 \\
\hline \multicolumn{5}{|c|}{ Effects Specification } \\
\hline
\end{tabular}

\begin{tabular}{llll}
\hline \multicolumn{4}{l}{ Cross-section fixed (dummy variables) } \\
\hline \hline & Weighted Statistics & \\
\hline R-squared & 0,84 & Mean dependent var & 3,52 \\
\hline Adjusted R-squared & 0,79 & S.D. dependent var & 4,80 \\
\hline S.E. of regression & 0,96 & Sum squared resid & 107,16 \\
\hline F-statistic & 18,62 & Durbin-Watson stat & 1,89 \\
\hline Prob(F-statistic) & 0,00 & &
\end{tabular}

Berdasarkan model estimasi yang terpilih, diperoleh persamaan model regresi data panel sebagai berikut :

$$
\text { ROAit }=12,57-0,01 \text { KMit + 0,02 MLit - 1,67 SIZEit }
$$

Nilai konstanta $\alpha$ sebesar 12,57 artinya jika variabel kepemilikan manajerial (KM), manajemen laba (ML) dan ukuran perusahaan (SIZE) pada observasi ke i dan periode ke $t$ di abaikan atau bernilai nol maka kinerja perusahaan (ROA) naik sebesar 12,57 persen.

Nilai koefisien b1 sebesar -0,01 artinya jika kepemilikan manajerial (KM) pada observasi ke i dan periode ke t meningkat sebesar satu (1) satuan, maka kinerja perusahaan (ROA) turun sebesar 0,01 dengan asumsi variabel manajemen laba (ML) dan ukuran perusahaan (SIZE) diabaikan.

Nilai koefisien b2 sebesar 0,02 artinya jika nilai manajemen laba (ML) pada observasi ke i dan periode ke t meningkat sebesar satu (1) satuan, maka kinerja perusahaan (ROA) naik sebesar 0,02 dengan asumsi variabel kepemilikan manajerial (KM) dan ukuran perusahaan (SIZE) diabaikan.

Nilai koefisien b3 sebesar -1,67 artinya jika nilai ukuran perusahaan (SIZE) pada observasi ke i dan periode ke t meningkat sebesar satu (1) satuan, maka kinerja perusahaan (ROA) turun sebesar 1,67 dengan asumsi variabel kepemilikan manajerial (KM) dan manajemen laba (ML) diabaikan.

\section{Pengujian Hipotesis Secara Parsial (Uji-t)}

Uji t digunakan untuk menguji pengaruh independent variable secara parsial terhadap variable dependent. Pengujian ini dilakukan dengan ketentuan :

1. Apabila probability thitung $<0,05$, maka Ho ditolak dan Ha diterima.

2. Apabila probability thitung $>0,05$, maka Ho diterima dan Ha ditolak. 
Berdasarkan tabel 8 menunjukan pengaruh variabel kepemilikan manajerial, manajemen laba dan ukuran perusahaan terhadap kinerja perusahaan (ROA) sebagai berikut,yaitu :

1. Kepemilikan manajerial terhadap kinerja perusahaan

Hasil analisis menunjukkan kepemilikan manajerial (KM) memiliki nilai koefisien regresi sebesar $-0,01$ dan tstatistic sebesar $-0,42$ dengan nilai probability sebesar 0,67 lebih besardari 0,05 atau $(0,67>0,05)$. Maka dapat disimpulkan bahwa variabel kepemilikan manajerial (KM) secara parsial tidak berpengaruh signifikan terhadap kinerja perusahaan (ROA) pada perusahaan property dan real estate yang terdafatar di Bursa Efek Indonesia tahun 2014-2018. Sehingga Ho diterima dan Ha ditolak.

2. Manajemen laba terhadap kinerja perusahaan

Hasil analisis menunjukkan bahwa manajemen laba (ML) memiliki nilai koefisien regresi sebesar 0,02 dan tstatistic sebesar 0,56 dengan nilai probability sebesar 0,58 lebih besar dari 0,05 atau $(0,58>0,05)$. Maka dapat disimpulkan bahwa variabel manajemen laba (ML) secara parsial tidak berpengaruh signifikan terhadap kinerja perusahaan (ROA) pada perusahaan property dan real estate yang terdaftar diBursa Efek Indonesia tahun 2014- 2018. Sehingga Ho diterima dan Ha ditolak.

3. Ukuran perusahaan terhadap kinerja perusahaan

Menunjukkan bahwa variabel ukuran perusahaan (SIZE) memiliki nilai koefisien regresi sebesar -1,67 dan tstatistic sebesar -4,48 dengan nilai probability sebesar 0,00 lebih kecil dari 0,05 atau $(0,00<0,05)$. Maka dapat disimpulkan bahwa variabel ukuran perusahaan (SIZE) secara parsial berpengaruh signifikan terhadap kinerja perusahaan (ROA) pada perusahaan property dan real estate yang terdafatar di Bursa Efek Indonesia tahun 2014-2018. Sehingga Ho ditolak dan Ha diterima.

\section{Pengujian Hipotesis Secara Simultan ( Uji-F)}

Uji ini bertujuan untuk mengetahui apakah independent variable secara bersama-sama berpengaruh terhadap dependent variable dan juga untuk mengetahui ketepatan pemilihan variabel yang akan dibentuk kedalam sebuah model regrasi maka dilakukan pengujian F-statistik.

Berdasarkan tabel 4.9 menunjukan nilai F-statistik sebesar 18,62 dan probability sebesar 0,00 dengan tingkat kesalahan yang digunakan sebesar 0,05 . hasil yang diperoleh menunjukan bahwa nilai probability yang dihasilkan sebesar $0,00<0,05$ maka keputusannya adalah bahwa variabel kepemilikan manajerial (KM), manajemen laba (ML) dan ukuran perusahaan (SIZE) secara simultan berpengaruh signifikan terhadap kinerja perusahaan (ROA) pada perusahaan property dan estate yang terdaftar di Bursa Efek Indonesia pada tahun 2014-2018. Sehingga Ho ditolak dan Ha diterima.

Berikut ringkasan hasil pengujian hipotesis yang telah dilakukan adalah sebagai berikut :

Table 9: Hasil Pengujian Hipotesis Penelitian

\begin{tabular}{llllll} 
Hip. & Peryataan & Sign. & Pembanding & Keputusan \\
\hline H1 & $\begin{array}{l}\text { Diduga kepemilikan manajerial } \\
\text { berpengaruh signifikan terhadap } \\
\text { kinerja perusahaan }\end{array}$ & Ditolak \\
\hline H2 & $\begin{array}{l}\text { Diduga manajemen laba } \\
\text { berpengaruh signifikan terhadap } \\
\text { kinerja perusahaan }\end{array}$ & 0,05 & Ditolak \\
\hline H3 & $\begin{array}{l}\text { Diduga ukuran perusahaan } \\
\text { berpengaruh signifikan terhadap } \\
\text { kinerja perusahaan }\end{array}$ & Diterima \\
\hline H4 & $\begin{array}{l}\text { Diduga kepemilikan manajerial, 0,00 } \\
\text { manajemen laba dan ukuran }\end{array}$ & 0,05 & Diterima
\end{tabular}


perusahaan berpengaruh signifikan

terhadap kinerja perusahaan

\section{Uji Koofisien Determinasi $\left(\mathbf{R}^{2}\right)$}

Koefisien determinasi $\left(\mathrm{R}^{2}\right)$ menunjukkan proporsi yang diterangkan oleh independent variable dalam model terhadap dependent variable, sisanya dijelaskann oleh variabel lain yang tidak dimasukkan dalam model, formulasi model yang keliru dan kesalahan eksperimen. Hasil uji koefisien determinasi dapat dilihat pada tabel seperti berikut :

Table 10: Hasil Uji Koefisien Determinasi $\left(\mathrm{R}^{2}\right)$

\begin{tabular}{ll} 
R-squared & 0,84 \\
\hline Adjusted R-squared & 0,79
\end{tabular}

Catatan: Hasil Ouput Eviews 9

Berdasarkan tabel 10 menunjukan bahwa nilai koefisien determinasi yang dihasilkan dalam pengujian $R$-squared bernilai 0,84 . Hasil yang diperoleh menunjukan bahwa kepemilikan manajerial (KM), manajemen laba (ML) dan ukuran perusahaan (SIZE) mampu memberikan kontribusi dalam mempengaruhi kinerja keuangan (ROA) sebesar $84 \%$ sedangkan sisanya $16 \%$ lagi dipengaruhi oleh variabel lainnya yang tidak dimasukkan dalam model penelitian.

\section{Hasil dan Pembahasan Penelitian}

Adapun pembahasan dari hasil penelitian yang telah dilakukan adalah sebagai berikut:

1.Pengaruh Signifikan Kepemilikan Manajerial (X1) terhadap Kinerja Perusahaan (Y)

Berdasarkan hasil yang diperoleh dari pengujian terhadap regresi, didapatkan nilai koefisien regresi sebesar $-0,01$ dan tstatistic sebesar $-0,42$ dengan nilai probability sebesar 0,67 lebih besar dari 0,05 atau $(0,67>0,05)$. Maka dapat disimpulkan bahwa variabel kepemilikan manajerial $(\mathrm{KM})$ secara parsial tidak berpengaruh signifikan terhadap kinerja perusahaan (ROA) pada perusahaan property dan real estate yang terdafatar di Bursa Efek Indonesia tahun 2014-2018. Artinya bahwa Kepemilikan Manajerial (KM) tidak mempunyai pengaruh terhadap Kinerja Perusahaan. Ada atau tidak adanya kepemilikan manajerial pada perusahaan Property dan Real Estate tidak menjadikan kinerja perusahaan baik atau buruk, sebab kepemilikan manajerial (KM) hanyalah wujud dari kepemilikan saham para struktural di perusahaan. Maka dari itu kepemilikan manajerial tidak berpengaruh terhadap kinerja perusahaan. Besar kecilnya kepemilikan manajerial tidak memberikan dampak terhadap peningkatan kinerja perusahaan. Hal ini berarti ada atau tidak adanya kepemilikan manajerial pada perusahaan Property dan Real Estate tidak menjadikan kinerja perusahaan baik atau buruk. Hasil penelitian ini sejalan dengan penelitian yang dilakukan oleh Yus Epi (2017).

2.Pengaruh Signifikan Manajemen Laba (X2) terhadap Kinerja Perusahaan (Y)

Berdasarkan hasil yang diperoleh dari pengujian terhadap regresi, didapatkan nilai koefisien regresi sebesar 0,02 dan tstatistic sebesar 0,56 dengan nilai probability sebesar 0,58 lebih besardari 0,05 atau $(0,58>0,05)$. Maka dapat disimpulkan bahwa variabel manajemen laba (ML) secara parsial tidak berpengaruh signifikan terhadap kinerja perusahaan (ROA) pada perusahaan property dan real estate yang terdaftar di Bursa Efek Indonesia tahun 2014-2018. Manajemen laba merupakan suatu intervensi dengan maksud tertentu terhadap proses pelaporan keuangan eksternal dengan sengaja untuk memperoleh beberapa keuntungan pribadi. Maka dari itu manajemen laba tidak berpengaruh terhadap kinerja perusahaan dikarenakan manajemen laba memiliki pelaporan keuangan dalam menyusun transaksi untuk mengubah laporan keuangan serta menyesatkan stakeholders mengenai kinerja perusahaan. Perilaku yang dilakukan oleh manajer perusahaan adalah untuk meningkatkan atau menurunkan laba dalam proses pelaporan keuangan eksternal dengan tujuan untuk menguntungkan dirinya sendiri. Hasil penelitian ini sejalan dengan penelitian 
yang dilakukan oleh Lucy Citra Fitriany (2016).

3.Pengaruh Signifikan Ukuran Perusahaan (X3) terhadap Kinerja Perusahaan (Y)

Berdasarkan hasil yang diperoleh dari pengujian terhadap regresi, didapatkan nilai koefisien regresi sebesar -1,67 dan tstatistic sebesar -4,48 dengan nilai probability sebesar 0,00 lebih kecil dari 0,05 atau $(0,00<0,05)$. Maka dapat disimpulkan bahwa variabel ukuran perusahaan (SIZE) secara parsial berpengaruh signifikan terhadap kinerja perusahaan (ROA) pada perusahaan property dan real estate yang terdafatar di Bursa Efek Indonesia tahun 2014-2018. Ukuran perusahaan adalah suatu skala dimana dapat diklasifikasikan besar kecilnya perusahaan menurut berbagai cara antara lain dengan total aset, nilai pasar saham, dan lain-lain. Ukuran perusahaan dianggap mampu mempengaruhi kinerja perusahaan karena semakin mudah bagi perusahaan dalam memperoleh sumber pendanaan, baik yang bersifat internal maupun eksternal. Ukuran perusahaan yang besar akan lebih menguntungkan pihak perusahaan dalam aktivitas pendanaan perusahaan di pasar modal. Hasil penelitian ini sejalan dengan penelitian yang dilakukan oleh Prasetyorini (2017)

4.Pengaruh Signifikan Kepemilikan Manajerial (X1), Manajemen Laba (X2) dan Ukuran Perusahaan (X3) terhadap Kinerja Perusahaan (Y)

Berdasarkan hasil pengujian menunjukkan nilai F-statistik sebesar 18,62 dan probability sebesar 0,00 dengan tingkat kesalahan yang digunakan sebesar 0,05 . hasil yang diperoleh menunjukan bahwa nilai probability yang dihasilkan sebesar $0,00<0,05$ maka keputusannya adalah bahwa variabel kepemilikan manajerial (KM), manajemen laba (ML) dan ukuran perusahaan (SIZE) secara simultan berpengaruh signifikan terhadap kinerja perusahaan (ROA) pada perusahaan property dan estate yang terdaftar di Bursa Efek Indonesia pada tahun 2014-2018.

\section{Kesimpulan}

Kesimpulan harus memberikan ringkasan:

a. Secara persial (Uji-t) menunjukkan bahwakepemilikanmanajerial dan manajemen laba tidak berpengaruh signifikan terhadap kinerja perusahaan, sedangkan ukuran perusahaan berpengaruh signifikan terhadap kinerja perusahaan. Hasil secara simultan (Uji-f) kepemilikan manajerial, manajemen laba dan ukuran perusahaan signifikan terhadap kinerja perusahaan. Kontribusi kepemilikan manajerial, manajemen laba dan ukuran perusahaan terhadap kinerja perusahaan sebesar $84 \%$, sedangkan sisanya $16 \%$ dipengaruhi oleh variable lain yang tidak dimasukkan dalam model pada penelitian ini.

b. Untuk dapat mengembangkan penelitian ini dengan memperbanyak sampel, menambah periode waktu penelitian, mengganti proksi serta menggunakan variabel-variabel lain yang mungkin berpengaruh terhadap kinerja perusahaan.

\section{Daftar Pustaka}

[1] Sudaryono. (2017). Pengantar Manajemen Teori dan Kasus. Yogyakarta: PT Buku Seru.

[2] Fajar Nur'aini Dwi Fatimah. (2017). Pendahuluan Praktis Evaluasi Kinerja Karyawan. Bantul: PT Anak Hebat Indonesia.

[3] Basuki dan Prawoto. (2016). Regresi dalam Penelitian Ekonomi dan Bisnis. Jakarta: PT Raja Grafindo Persada.

[4] Hery. (2017). Kajian Riset Akuntansi. Jakarta: Pt Grasindo.

[5] Lupioyadi, dan Ikhsan. (2015). Pratikum Metode Riset Bisnis. Jakarta Selatan: PT Salemba Empat.

[6] Sugiarto. (2017). Metodologi Penelitian Bisnis. Yogyakarta: CV.Andi Offset.

[7] Umar. (2014). Metode Penelitian untuk Skripsi dan Tesis Bisnis. Jakarta: PT Raja Grafindo Persada.

[8] Hery. (2014). Analisis Kinerja Manajemen. Jakarta: PT Grasindo, anggota Ikapi.

[9] Winwin Yadiati. (2017). Kualitas Laporan Keuangan. Jakarta: Kencana 
[10] Subagyo dkk. (2017). Akuntansi Manajemen Berbasis Desain. Yogyakarta: Gadjah Mada University Press

[11] Mukhtar Galib. (2018). Analisis Kinerja Perusahaan dengan Menggunakan Pendekatan Balanced Scorecard pada PT.Bosowa Propertindo. Jurnal Manajemen. Program Pascasarjana STIE Amkop Makassr. Vol. 2 No. 12018

[12] Melia Agustina Tertius dan Yulius Jogi Christiawan. (2015). Pengaruh Good Covernance terhadap Kinerja Perusahaan pada Sektor Keuangan. Business Accounting Review Vol. 3, No. 1, Januari 2015: 223-232

[13] Yus Epi. (2017). Pengaruh Ukuran Perusahaan, Struktur Kepemilikan Manajerial dan Manajemen Laba Terhadap Kinerja Perusahaan Property dan Real Estate yang Terdaftar pada Bursa Efek Indonesia. Riset \& Jurnal Akuntan. Volume 1 Nomor 1, Februari 2017. ISSN : 2548 - 9224

[14] Mudrika Alamsyah Hasan. (2014). Pengaruh Kepemilikan Manajerial, Free Cash Flow dan Ukuran Perusahaan terhadap Kebijakan Utang (Studi pada Perusahaan -Perusahaan Industri Dasar dan Kimia yang Terdaftar di BEI). Jurnal Akuntansi, Vol. 3, No. 1, Oktober 2014 : 90 - 100

[15] Lusyana Ale. (2014). Pengaruh Ukuran Perusahaan, Leverage, Kepemilikan Institusional dan Ukuran Dewan Komisaris Terhadap Pengungkapan Corporate Social Responsibility. Alumnus Fakultas Ekonomi Universitas Atma Jaya Yogyakarta

[16] Filicia1, Raisa Pratiwi. (2017). Pengaruh Pengungkapan Corporate Social Responsibility, Struktur Kepemilikan Asing dan Ukuran Perusahaan Terhadap Agresivitas Pajak (Studi Empiris Pada Perusahaan Manufaktur Yang Terdaftar Di Bursa Efek Indonesia 2015-2017).

[17] Herlina Wijayanti dkk. (2014). Pengaruh Manajemen Laba Riil Terhadap Kinerja Perusahaan Dengan Pendekatan Arus Kas Operasi. Jurnal Economia, Volume 10, Nomor 1, April 2014

[18] Nieken Herma Sari dan Nurmala Ahmar. (2014). Revenue Discretionary Model Pengukuran Manajemen Laba: Berdasarkan Sektor Industri Manufaktur di Bursa Efek Indonesia. Jurnal Akuntansi dan Keuangan, Vol. 16, No. 1, Mei 2014, ISSN 1411-0288

[19] Deby Anastasia Meilic Theacini, I Gde Suparta Wisadha. (2014). Pengaruh Good Corporate Governance, Kualitas Laba dan Ukuran Perusahaan pada Kinerja Perusahaan. E-Jurnal Akuntansi. Universitas Udayana 7.3 (2014). ISSN: 2302-8556

[20] Titis Waskito. (2014). Pengaruh Struktur Kepemilikan Manajerial, Kepemilikan Institusional, dan Ukuran Perusahaan Terhadap Kinerja Keuangan. Universitas Muhammadiyah Surakarta

[21] Domas Titis Anggit, Muhammad Ja'far Shodiq. (2014). Hubungan Antara Mekanisme Corporate Governance, Manajemen Laba dan Kinerja Keuangan. SNA 17 Mataram, Lombok Universitas Mataram 24-27 Sept 2014

[22] Arum Ardianingsih, Komala Ardiyani. (2014). Analisis Pengaruh Struktur Kepemilikan Terhadap Kinerja Perusahaan. Jurnal Pena, Vol. 19 No. 2, September 2010

[23] Shierly Pricilia, dan Liana Susanto. (2017). Pengaruh Kepemilikan Institusional, Kepemilikan Manajerial, Komisaris Independen, dan Ukuran Dewan Komisaris Terhadap Manajemen Laba Serta Implikasinya Terhadap Kinerja Keuangan Pada Perusahaan Manufaktur yang Terdaftar di Bursa Efek Indonesia Periode 2012-2014. Jurnal Ekonomi. Vol. XXII, No. 02, Juli 2017

[24] Adil Ridlo Fadillah. (2017). Analisis Pengaruh Dewan Komisaris Independen, Kepemilikan Manajerial dan Kepemilikan Institusional Terhadap Kinerja Perusahaan yang Terdaftar di LQ45. Jurnal Akuntansi Vol 12, Nomor 1, Januari Juni 2017

[25] Raras Mahiswari, Paskah Ika Nugroho. (2014). Pengaruh Mekanisme Corporate Governance, Ukuran Perusahaan dan Leverage Terhadap Manajemen Laba dan Kinerja Keuangan. Vol. XVII No. 1. APRIL 2014. ISSN 1979-6471

[26] Ajeng Asmi Mahaputeri, I.Kt.Yadnyana. (2014). Pengaruh Struktur Kepemilikan, Kebijakan Pendanaan dan Ukuran Perusahaan pada Kinerja Perusahaan. E-Jurnal Akuntansi Universitas Udayana. 9.1 (2014). ISSN: 2302-8556

[27] Nopi Puji Lestari, Agung Juliarto. (2017). Pengaruh Dimesi Struktur Kepemilikan Terhadap Kinerja Perusahaan Manufaktur. Diponegoro Journal Of Accounting. Vol 6, Nomor 3, Tahun 2017. ISSN 2337-3806

[28] Ardi Wiranata. (2017). Pengaruh Struktur Kepemilikan, Struktur Modal, dan Ukuran Perusahaan Terhadap Kinerja Perusahaan. JOM Fekon Vol.4 No.2 (Oktober) 2017 